\title{
Covid-19: Guidance is still lacking on how ethnic minorities can protect themselves better, say MPs
}

\section{Shaun Griffin}

Pre-existing inequalities in health, employment, housing, and access to Universal Credit created a "perfect storm" of factors that have exacerbated the effects of coronavirus on minority ethnic communities, an influential committee of MPs has said.

To tackle these inequalities the House of Commons Women and Equalities Committee has made 18 recommendations, which its chair, Caroline Nokes, says will help to "rebuild society in an equal, fairer way.” Most urgent is the need for culturally competent guidance, says the committee's report into the effects of the covid pandemic on people from ethnic minority communities. ${ }^{1}$

Despite concerns having been raised since the beginning of the pandemic that advice and guidance had not been targeted to different communities ${ }^{2}$ this is still happening, says the report. It is not sufficient to simply translate guidance into other languages without an understanding of cultural nuances, it adds, and the government must liaise with minority ethnic women in cascading such guidance.

Nokes explained, "Even with vaccines now providing an end in sight, preventative measures will still need to be taken to limit infection, [as] many individuals will still need to self-isolate in overcrowded housing.

"And the success of a mass vaccination programme will rely on clear guidance and information reaching everyone. The government must ensure that communication is targeted and designed for different communities and disseminated in a manner which encourages trust."

\section{Community champions}

Nine months after the country first entered lockdown there is still no clear guidance on how to overcome the challenges of living in overcrowded or multigenerational accommodation, the report says. The committee has called on the government to provide clear, culturally competent guidance within the next four weeks, with practical recommendations on how to self-isolate in those conditions, and to liaise with minority ethnic women to encourage them to become community champions to reach people who are marginalised.

Better ethnicity data are needed across the board, the report adds, but especially coronavirus related data. The report calls on the government to collect and report disaggregated data on testing, infection, and deaths and to consider allowing informants to report ethnicity when deaths are registered.

The report states, “The government should collect, and report, disaggregated data on clinical outcomes, for instance, the share of BAME [black, Asian, and minority ethnic] people being tested, how many have tested positive and the share of BAME people being admitted to hospital. We believe that this is essential in assessing the impact of coronavirus on BAME people; any data collected should be disaggregated by ethnic group to allow for a much more granular analysis of the problems."

On employment, the report recommends that the government should examine the interaction between ethnicity, occupation, and coronavirus outcomes and that the Equality and Human Rights Commission should look for evidence of a causal link between occupation and rates of covid-19 exposure, infection, and mortality.

\section{Disproportionate rates}

Responding to the report, Chaand Nagpaul, BMA chair of council, repeated the call for action on inequalities to prevent further harm.

He said, "Despite government reassurance that it is addressing these issues, we continue to see disproportionate rates of people from BAME backgrounds being treated for covid-19 in intensive care, while areas with larger non-white populations continue to have higher infection rates. It is clear that the action taken to date is nowhere near enough.

"Much of this report should come as no surprise to the government, and it's imperative that ministers take up the recommendations, acting urgently to protect the lives and livelihoods of those hit hardest by the effects of this virus."

The report also calls for the recommendations made in Health Equity in England: The Marmot Review 10 Years On, published earlier this year, ${ }^{3}$ to be implemented. Marmot's further follow-up report highlighting the impact of inequalities on covid-19, which makes similar recommendations, was published this week. ${ }^{4}$

\footnotetext{
House of Commons Women and Equalities Committee. Unequal impact? Coronavirus and BAME people. Dec 2020. https://committees.parliament.uk/publications/3965/documents/39887/default/.

2 lacobucci G. Covid-19: Increased risk among ethnic minorities is largely due to poverty and social disparities, review finds. BMJ2020;371:m4099. doi: 10.1136/bmj.m4099 pmid: 33093063

3 lacobucci G. Marmot 10 years on: austerity has damaged nation's health, say experts. BM/2020;368:m747. doi: 10.1136/bmj.m747 pmid: 32098785

$4 \quad$ Griffin S. Covid-19: Failure to control pandemic and inequalities made England worst affected in Europe, says report. BMJ2020;371:m4842. doi: 10.1136/bmj.m4842 pmid: 33318131

This article is made freely available for use in accordance with BMJ's website terms and conditions for the duration of the covid-19 pandemic or until otherwise determined by BMJ. You may use, download and print the article for any lawful, non-commercial purpose (including text and data mining) provided that all
} copyright notices and trade marks are retained. 